\title{
ROAD TRAFFIC ACCIDENTS IN IRAQ: A REVIEW OF EVIDENCE- BASED LITERATURE
}

\author{
Firas Hasan Alwan Asad ${ }^{1}$ \\ ${ }^{1}$ Department of Civil Engineering, Faculty of Engineering, University of Kufa, Iraq
}

Received 28 January 2017; accepted 25 April 2017

\begin{abstract}
The overall aim of this paper is to enrich the global highway safety knowledge by shedding light on the current status of road safety in Iraq. Iraq is one of the major mediumincome Arabic countries in which vehicular road transport is the essential means of mobility. Recently, there has been a noticeable increase in traffic accidents and injuries; this increase is expected to be as an intuitive result of the soaring motorization which in turned is expected to be a result of the boom in economy and population after 2003. Available evidence-based literature concerning status of traffic accidents in Iraq over the past decade (2005-2015) has been analytically reviewed. Such literature includes official statistics, traffic accident studies, and current highway safety policies and traffic laws. The discussion of the synthesis of evidence-based findings revealed several important points regarding aspects such as crash characteristics, occurrence, severity, and measures. The findings can be informative for researchers interested in studying highway safety in developing countries. Also findings can guide the government to achieve its national goal in minimizing accidents and injuries. The paper attains its significance from being the first paper among those available online with timescale, spatial coverage and analytical scope sufficient to consider the preset aim.
\end{abstract}

Keywords: fatality rate, systematic review, road injuries, risk factors, contributing factors, road toll.

\section{General}

Iraq is one of the major Arabic countries with total area in access of $438,000 \mathrm{sq} \mathrm{km}$ and total population of about 37 million; around $70 \%$ of them live in urban areas. Geographically, Iraq is with latitude and longitude of $33^{\circ} 00^{\prime} \mathrm{N}$ and $44^{\circ} 00^{\prime} \mathrm{E}$ respectively and regionally is located within the Middle East in Southwest Asia. Major cities include the capital Baghdad, Al-Mosul, Al-Basra and Al-Sulaymaniyah. With over $59,600 \mathrm{~km}$ total paved roadways and 4.5 million total motor vehicles, road transport is the essential means of mobility for people and goods.

\footnotetext{
${ }^{1}$ Corresponding author: firas.alwan@uokufa.edu.iq
}

Road accident occurrence and severity have been highway safety issues for long years in Iraq. This challenge has become a lifethreatening issue after the continuous steep rise in vehicle ownership and thus use after 2003. That is when the economy started to recover after the gradual removal of economic sanctions imposed by the UN Security Council against Iraq subsequent to the invasion of Kuwait by the regime in 1990. It is heavily reported in the literature that rise in road vehicles is crucial to highway safety (Peden et al., 2004); furthermore, this rise can be an essential contributing factor to collision occurrence especially when no effective management programs are adopted (Mohan et al., 2006). 
The overall aim of this paper is to enrich the global highway safety literature by shedding light on the current status of road accidents in Iraq. In so doing three objectives have been set up: first, to shed light on the available official statistics relevant to traffic accidents; second, to review available evidence-based literature addressing traffic accident in Iraq over the past decade (20052015); and third, to run over the current highway safety policies and traffic laws. The findings can inform researchers and organizations interested in studying highway safety in developing countries. The current paper attains its significance from being the first paper among those currently available online that with timescale, spatial coverage and analytical scope sufficient to consider the three above objectives.

\section{Evidence from Statistics}

Several indicators and measures are usually adopted to quantify the status of road accidents in an area. These indicators are also effective tools to compare characteristics of accidents spatially and temporally. Number of accidents, number of deaths, number of injuries and mortality rate are the main repeatedly employed accident indicators in highway accident studies. Since one of the fundamental consequences of accidents is their adverse direct impacts on public life and health, mortality rate indicator is thus usually adopted to quantify these impacts. Based on the statistics reported in the World Health Organization (WHO) report regarding global status of road safety (WHO, 2015), Fig. 1 has been developed to compare crash mortality rate of Iraq globally and regionally. The traffic accidents mortality rate over Iraq in 2013 is 20.2. Mathematically, the Fig. 1 represents the number of road toll traffic deaths per 100,000 people. Globally, this rate is moderately higher than the worldwide rate of 17.4. Moreover, according to the WHO report Iraq ranks $113^{\text {th }}$ in the global list in which Monaco ranks first with zero mortality rate and Libya ranks $180^{\text {th }}$ (last) with 73.4 mortality rate. Regionally, in comparison with its six bordering countries, Iraq positions as the median with fatality rate (20.2) is just under the mean rate of 20.6. Unlike others, rate of Syria belongs to 2010 because of the recent unrest in the country due to terrorism.

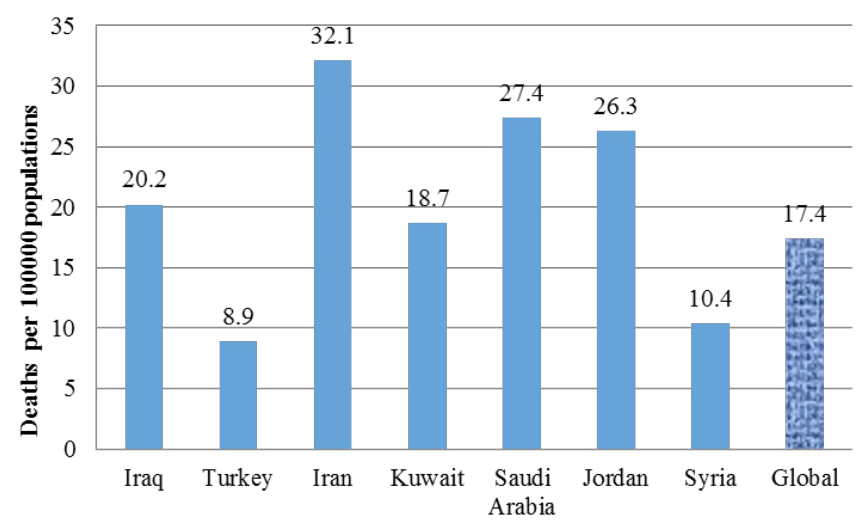

Fig. 1.

Road Accidents Fatality Rates for Selected Countries (Based on Statistics Reported in WHO Report) 
Source: World Health Organization (2015)

Table 1 (See Appendix), in contrast, lists key available statistics and indicators relevant to highway accidents over Iraq's roads network during the analysis period (2005-2015). There are several important points that should be highlighted:

- According to the Central Statistical Organization (CSO) of the Iraqi Ministry of Planning, there has been a steady increase in the population (CSO, 2011; CSO, 2015a; CSO, 2016a; CSO, 2016b).

- Based on statistics extracted from the World Bank report (The World Bank, 2016), there has been an overall enhance in the economic status of Iraqi people. The Gross National Income (GNI) per capita is one of the adopted indicators by the World Bank for quantifying economy health of countries and standard of living for citizens. GNI per capita imitates the average annual income of individuals.

- According to the CSO (CSO, 2011; CSO, 2013d; CSO, 2015a; CSO, 2016c), the number of vehicles has been considerably increased. The number of vehicles in 2015 (5.66 million) is five times that in 2007 (1.13 million). This increase sounds as a typical consequence for the joined boom in population and economy.

- According to the CSO reports, during the period 2006-2015 an uptrend line for the number of crashes, number of casualties and mortality rate can be obviously noticed (CSO, 2013a; CSO, 2013b; CSO, 2013c; CSO, 2013d; CSO, 2014; CSO, 2015b; CSO, 2015c; WHO, 2015). This positive trend can be seen as an intuitive result of the unplanned increase in car ownership and hence car use. Rise in car use means in one way or another rise in the opportunity of exposing to risk of a crash.

\section{Evidence from Literature}

A thorough and topic-specific search of studies has been carried out. The goal is to end up with evidence-based literature. The inclusion criteria involve any research article (mainly journal paper or conference proceedings) with at least one of its objective or research questions is to tackle traffic accidents in Iraq during the period (20052015). Title and abstract have been used as the basis for identifying and selecting the target studies. Keywords such as accident, crash, collision and injuries together with keywords such as highway, road, traffic, vehicle and car have been utilized alternatively to narrow the search. The vast majority of the target studies have been retrieved from the Iraqi Academic Scientific Journals website (http://www.iasj.net); an official platform for scholarly Iraqi journals developed by the Iraqi Ministry of Higher Education and Scientific Research in 2012. Most probably that is because each university in Iraq has at least one research journal and Iraqi researchers mostly publish their papers in these journals. According to the IASJ website, the platform contains more than 99600 articles and 249 academic open access peer-reviewed journals published by 48 research institutions. The search strategy also included searching reports and articles published by the Iraqi Ministry of Transport.

The survey of road safety articles has revealed a lack in the required studies. Speaking in numbers, the search of literature has only ended up with a total of 26 research paper published online over the past 10 years (2005-2015). In general, these papers 
reflect the current knowledge regarding the epidemiology, morbidity and mortality of traffic accidents in Iraq. In spite of being relevant, the retrieved studies are different in one or more of the basic methodological aspects such as objectives, data sources, research design, analysis methods and last but not least findings. For the convenience of reader, Table 2 (See Appendix) exhibits the retrieved studies. In the first column the studies have been ordered chronologically; whereas their objectives have been listed in the second column. A brief description of the accident data including source, sample size, temporal and spatial coverage has been listed under the third column. Also a brief about type of research design and method of data analysis for each study has been reported in the forth column. The last column lists the key findings relevant to traffic accidents.

\subsection{Objectives}

The ultimate target of accident studies is to prevent crash and, if occurred, to prevent injuries or at least to reduce their severity. In so doing, the vast majority of reviewed studies are with two-fold essential objectives; first, to study the epidemiology of traffic accidents and second, to examine their mortality and morbidity (See Table 2). More specific, the reviewed studies have tackled the possible impacts of several risk and contributing factors on several accident indicators and measures. Table 3 (See Appendix) depicts a cross-tabulation for the names and numbers of these studies.

\subsection{Data Sources}

After determining the temporal and spatial scope of research presumably compatible with the presets objectives, the researcher should now decide how to obtain the data required for the analysis. Basically, surveys of traffic studies are classified into observational and participatory (O'Flaherty, 1997). Accident surveys are often of the second type (interviews or questionnaire forms) since traffic accidents are usually considered infrequent and unpredictable events temporally and spatially and hence fairly difficult to be observed directly (Roess et al., 2011). Most of the traffic accident surveys in the retrieved studies are participatory. Alternatives techniques based on collecting quasi-crash field data such as Traffic Conflict Technique and Diagnosis Technique are sometimes employed to perform accident analysis. Five of the retrieved studies have employed these techniques (See Table 2).

Traffic accident data comes from two essential sources; primary and secondary. Primary sources includes virgin data collected by the researcher for the first time; usually by approaching respondents (often road users previously involved in a traffic collision) through face-to-face interview or by self-completion questionnaires. Secondary sources, in contrast, involve compiling crash data previously collected and published from one or more sources such as official records, government reports and previous research. Table 2 shows that 14 of the retrieved studies have utilized previously gathered accidents data from secondary sources such hospital patient's records; police records; province traffic directorates and official reports from the Iraqi Central Statistics Organization CSO. The table also shows that only 9 studies have conducted participatory survey to collect original data. The heavy reliance on crash data obtained from police and hospital records is highlighted in the literature; see for example Peden et al. (2004) and Roess 
et al. (2011). In Iraq, finance and security agreements are the main challenges for conducting traffic accident participatory surveys.

\subsection{Methodology}

With respect to the spatial coverage of the research conducted in the reviewed studies, Table 2 shows that five of them are nationwide, 19 are province-wide while others have no specific spatial scope. According to literature, there is variety of ways that research designs can be classified in; reviewing these ways is beyond the scope of the current paper. However, it is agreed that studies can be generally designed into two essential groups; experimental and nonexperimental. The dominant difference is that in experimental research (field or laboratory setting alike) the researcher has a clear role in assigning the intervention (exposure) to the treatment group and then monitoring the resulting effects -if any- on the outcome. When this role in administering the intervention is practically not feasible ethically unacceptable or legally impermissible the non-experimental research design appears as an attractive alternative. In the non-experiment design the researcher role is solely observing group of cases with specific outcome; hence sometimes are called observational. In general, there are two basic types of observational studies; descriptive and correlational. While descriptive studies aim only to describe or explore study variables, correlational studies aim to examine whether the outcome is associated - statistically speaking correlatedwith some risk factors. Detailed information about methods of research designs can be found in Marczyk et al. (2005) and Bordens and Abbott (2008). Last but not least, experimental design requires investigator to assign cases to treatment group and control group randomly. When the randomness is not satisfied, the design is often called quasi-experimental. In accident studies, before-and-after studies are good example of such design.

According to Table 3, the outcome usually includes crash frequency, crash occurrence, crash involvement or crash severity. In contrast, predictor variables are usually risk variables or factors expected to be contributory to crash. However, all the retrieved studies fall under the umbrella of non-experimental (observational) research design. Last but not least, while generally data analysis can be carried out quantitatively or qualitatively, all the retrieved studies employed quantitative approach to analyze crash data. In addition, three methods of data analysis have been employed; descriptive, exploratory and inferential.

\subsection{A Synthesis of Key Findings}

For the sake of convenience and ease of comparability, the studies dealt with one or more of the accident measures (indicators) have been cross-classified in Table 3 according to the analytic variables (usually risk factors) employed in their analysis. Table 3 reveals that there is a lack in the studies examining the impacts of conditions of road, vehicle and weather on the accident involvement, severity and type. Following is a synthesis of the key findings of the total tabulated studies.

\subsubsection{Road Users Attributes}

Reviewing the retrieved studies confirms that road users are one of the leading causes of collisions (Jrew et al., 2015); speaking in numbers, human factors account for about 
$86 \%$ of total collisions (Al-Hucheimy, 2014). More specific, among other road users motorists have the primary contribution to road crashes (Zalzala and Mahmood, 2013); in numbers, $50 \%$ of the crashes are attributed to the motorist (Al-Obaedi, 2015).

In terms of gender, the majority of drivers are males (Al-Joborae and Al-Humairi, 2014; Ismail and Hasan, 2012; Muhammad, 2006). In terms of age, young people are the most involved cohort in road traffic accidents (Ali, 2005; Ismail and Hasan, 2012; Muhammad, 2006; Zalzala and Mahmood, 2013); this is compatible with what is internationally recognized (WHO, 2015). Majority of victims are with pre-university education level (Ismail and Hasan, 2012); in the same contest, it has been found that divers' understanding of the message a traffic sign convey is negatively associated with the number of crashes he/she involved in (Ismail, 2012). The type and position of victim's injury in Iraq are different from those reported in most foreign studies. This is probably because of the difference in driver behavior. For example, disobeying safety rules regarding wearing seat belts and leaving adequate safety distance are quite common in Iraq. The above interpretation was highlighted by Razouki et al. (2013). It has also been reported that improper parking, wrong turning and high speed are major causes of crashes (Mohammed, 2011). Approximately $75 \%$ of victims are not using safety seat belts (Ismail and Hasan, 2012), about $50 \%$ with no driving license and about $60 \%$ with collision history (Al-Joborae and Al-Humairi, 2014).

There is empirical-based evidence that in urban locations collisions involving pedestrians are greater than those among vehicles (Al-Obaedi, 2015). Nearly 50\% of casualties are pedestrians with about twothirds of them are less than 20 years old (Muhammad, 2006) or nearly half of them are less than 15 years old (Al-Obaidi et al., 2007).

\subsubsection{Road Conditions}

The impacts of traffic and geometric conditions of roads and streets on the occurrence and severity of accidents are intuitive. It has been reported that bad road condition is one of the essential risk factors of accidents (Dhahad, 2015; Jrew et al., 2015). For example, there is a strong proportional relationships linking hourly traffic volume or stopped time delay at intersections with the number of traffic conflicts (as a proxy of crashes) (Ewadh and Neham, 2008; Naham, 2009). Also traffic density has a clear impact on collisions (Jrew et al., 2015). Similarly, the studies have pointed out that intersection geometry has an impact on conflict rates (Ewadh and Neham, 2008; Jrew et al., 2015; Naham, 2009). Furthermore, traffic excessive speed has been empirically found with significant contribution to both occurrence and severity of collisions (Al-Joborae and Al-Humairi, 2014; Dhahad, 2015; Razouki et al., 2013). In contrast, regarding severity, (Jrew et al., 2015) pointed out that in urban areas the mortality is not significantly linked to the roads' traffic and geometric features.

\subsubsection{Weather Conditions}

Majority of crashes happened during the times with clear sky and good weather (AlJoborae and Al-Humairi, 2014; Dhahad, 2015; Razouki et al., 2013); however, it is suitable to mention here that the sky in Iraq is usually clear. There has been no consensus about association between accident rates 
and weather factors. For example whereas Mudfon and Abd Onn (2005) confirmed the influence of dust, fog, rain and high temperature on rates of collisions, Alwash (2012) stated that there is no such clear influence. Finally, Al-Joborae and AlHumairi (2014) reported that weather status could affect the severity of injury.

\subsubsection{Vehicle's Conditions}

Four-wheel vehicles have been found involved in a large proportion of collisions (Ismail and Hasan, 2012; Zalzala and Mahmood, 2013); more specific, over 50\% of collisions are by passenger cars (Mohammed et al., 2015). It has been reported that the vehicle is the contributor for about quarter of collisions (Al-Obaedi, 2015). In particular, whereas the occurrence of crash is largely affected by the periodic maintenance of vehicles (Dhahad, 2015), the crash morbidity and mortality is largely affected by the utilization of technological safety measures such as seat belts and airbags (Razouki et al., 2013). As an Intelligent Transport System (ITS) application, it has been also revealed that adopting a pre-crash system that support and monitor cars remotely can warn both motorists and monitoring center when local speed limit is exceeded or a crash is happened (Abid et al., 2014).

\subsubsection{Crash Characteristics}

With respect to the crash type, there is no agreement in findings. Whereas vehiclevehicle collision is the commonest collision in specific cities (Mohammed et al., 2015; Mohammed, 2011), run over was the commonest in another (Alwash, 2012). Most likely this is due to the fact that some cities have safety measures more pedestrianoriented than others. Regarding mortality and morbidity of road traffic accidents, several studies have reported that RTAs are the principal cause of death (Al-Obaidi et al., 2007; Ali, 2005; Muhammad, 2006). Fatality rates comprised about $28 \%$ of total crashes (Zalzala and Mahmood, 2013). More than half of the casualties have been found with head injury (Ismail and Hasan, 2012). Trauma severity can be considerably decreased by the availability and reliability of First Aids at collision site (Razouki et al., 2013).

Concerning time of accident, there is no strong agreement about when accidents frequently happen. However, studies have reported that highest rates of collision occurred in March (Alwash, 2012), in June (Mohammed et al., 2015; Mohammed, 2011) and in July (Alwash, 2012; Mohammed, 2011). Furthermore, accident analysis showed that majority of accidents have been occurred during daytime (Ismail and Hasan, 2012; Mohammed et al., 2015; Zalzala and Mahmood, 2013); and usually on Thursdays (Mohammed et al., 2015; Mohammed, 2011). It is worth mentioning that in Iraq wedding ceremonies usually hold on Thursdays; as a tradition the ceremony program usually involves a group of cars ranging over city main streets for fun. Sometimes this fun activity involves reckless driving and hence congestion and accidents are intuitive consequences.

With respect to the spatial analysis of accidents, several studies have reported that occurring of accidents more frequently on the main urban streets and highways (Al-Hucheimy, 2014; Al-Joborae and AlHumairi, 2014; Zalzala and Mahmood, 2013). This is probably for two reasons; first, urban street are usually more congested than others in the suburbs and rural locations 
and hence represents crash-prone locations. According to Tulfah (2008) there is a significant positive correlation between both vehicle-vehicle and run over collisions and the determinants of traffic congestion. Second, urban locations are typically highly populated and hence exposure level is high; it has been reported that $75 \%$ of crash victims live in such locations (Al-Joborae and AlHumairi, 2014). Similarly, Jrew et al. (2015) and Mohammed et al. (2015) have analyzed the spatial distribution of traffic accidents in order to locate and identify hazardous locations or black spots.

\subsubsection{Motorcyclists}

It is worthwhile noting that most of the studies have dealt with vehicle accidents, few of them dealt with motorcycle accidents. Those dealt with motorcycles; however, have reported that generally around $40 \%$ of motorcyclists involved in collisions are less than 20 years (Al-Ghabban et al., 2013; Mohammedhasan, 2009). Similarly, A1Anbari (2011) pointed out that motorcyclists comprise the majority of head injuries and they are generally males with less than 20 years old. According to Al-Ghabban et al. (2013), almost two-thirds of motorcyclists are only with primary school education, lower limb is the frequent location of injuries and head injuries are the main reason of mortality.

It is useful to highlight that some studies have adopted alternatives to crash records such as Traffic Conflicts Technique (TCT) (Al-Taei, 2010; Ewadh and Neham, 2008; Hadi, 2011; Naham, 2009) or the diagnosis-based safety evaluation approach (Mohammed, 2012). These studies have found these alternatives effective and useful especially when reliable crash data are unavailable.
Last, the discrepancies in the analysis results among studies may be attributed to the fact that majority of retrieved studies have focused on a specific city or province. Provinces differ in their accidents statistics since they differ in the efficiency of safety measures adopted in them. This has been confirmed by Ali and Abd (2015); they pointed that Iraqi provinces significantly vary in the frequency and severity of traffic accident.

\section{Policy Vision and Traffic Laws}

On the purpose of finalizing the whole picture regarding road accidents in Iraq, it is essential to shed light on the Iraqi Traffic Law and policy aspirations. Land Transport Law No. 50 in 1935 can be considered as the first documented Iraqi traffic law. After several amendments, the law was replaced with Traffic Law No. 48 in 1971. Similarly, after several amendments and due to rapid increase in motor cars, the law was replaced and revoked by the current into force Traffic Code (Order No. 86) issued in 2004 by the CPA (CPA, 2004). In general, the current Iraqi Traffic Law consists of 38 divisions. It starts by defining key terms regarding road components, vehicle types and road users. Several divisions are devoted for driving license, traffic violations and fines. The law supports and fosters highway safety through several approaches. For example, divisions 2,3 and 4 give details about driving license and how each driver should hold a valid one. Division 13 lists safety and durability conditions that should be available in each vehicle. In divisions 15, 16 and 17, driving rules, road rules and road priorities are given respectively. Specific divisions are devoted to careless driving and aggressive driving. Finally, in division 35 the law emphasizes that it is the duty of provincial traffic 
directorates to raise traffic awareness of public on the purpose of reducing accidents and regulating traffic.

In contrast, ensuring highway safety and minimizing traffic collisions are the national targets that explicitly highlighted in the Iraqi national policy documents. The national development plan (2010-2014) developed by the Iraqi Ministry of Planning clearly reported that the vision towards transport sector can be reached by achieving several specific objectives; one of them is reducing traffic accidents (Ministry of Planning, 2010).

In order to identify and quantify challenges that face the application of traffic law enforcement in the streets, four traffic police officers have been separately interviewed by the researcher. The question was 'as a field law enforcer, what are the factors that contribute to accidents?'. The answers can be summarized into two key points: (1) traffic fine are not big enough to act as effective financial deterrent and (2) many important parts of traffic law are not into force countrywide recently such as driving license, seat belt and speed limit.

Finally, it is important to highlight that Iraq has joined the global safety program called "Decade of Action for Road Safety 20112020" proclaimed by UN General Assembly in 2011 (WHO, 2011). The ultimate global target is to decrease road traffic crashes and injuries by 2020 .

\section{Discussion and Conclusions}

Utilizing fatality rate as an accident measure, Iraq's fatality rate per 100000 populations in
2013 is 20.2 which is fairly higher than the global average of 17.4 (See Fig. 1). Regionally, Iraq's fatality rate lies in the middle among the rates of countries surrounding it. These statistics make adopting effective technological and behavioral safety measures as an urgent necessity. In contrast, local statistics related to highway safety (See Table 1) show that the recent soaring motorization in Iraq is associated with the joined boom in population and economy. Soaring motorization can be seen as the most likely contributing factor to the numbers of collisions, casualties and deaths. That is because rise in vehicle ownership means rise in vehicular travel which in turns means rise in the exposures to the risk of a road collision.

According to the retrieved studies, there is literature-based evidence about key characteristics of traffic accidents over Iraq's roads and street. Regarding road users, the results are in agreement with the international knowledge in that road users in general and motorists in particular account for the majority of crashes. Furthermore, being the majority of casualties are young and thus mostly economically-active this should warn government and all road safety stakeholders about the expected economic negative impacts of accidents. In addition, in urban areas there is an agreement that most of casualties are pedestrians. Based on this evidence local government should take quick and serious steps in fostering effective plans regarding pedestrian safety and walkingdemand management. Also studies have reported that drivers and motorcyclists are generally with low knowledge about road signs, not wearing seat belts and driving without license. These findings justify the 
importance of holding traffic awareness campaigns and enforcing deterrent traffic laws if accidents frequency and severity are required to be minimized. With respect to gender, motorists are usually males. The reason behind that is twofold; first, in spite of it has recently become quite common to see a woman drives still there are people who consider that as a socially unacceptable behavior. The second reason is that generally in Iraq man is the breadwinner, hence a second car-assuming affordable- to be used by the wife is not a real necessity.

Regarding road conditions, there is an agreement about the association between the traffic and geometric conditions of roads on traffic accidents; improper intersection design and excessive speed are typical examples. This can inform policy makers and local governments to invest in enhancing the geometric design of road components with controlling speed as a specific target. Concerning vehicle conditions, ensuring periodic maintenance and provision of technological interventions such as airbags could minimize accidents and injuries. Literature-based evidence also implies that traffic management plans should prepared for non-normal days such as Thursdays where inattentive and aggressive driving is highly expected. Moreover, recalling that it is agreed that accidents are more frequently on the main streets of cities and other urban areas then investments should be focused on these locations.

Finally and to sum up, bearing in mind that both the national statistics and the evidencebased literature emphasize that significant proportion of mortality are due to RTAs, thus adopting effective safety strategies with efficient implementation plans is a necessity.

\section{References}

Abid, A.J.; Ali, R.S.; Saheb, R.R. 2014. Vehicle Remote Support and Surveillance System, Iraqi Journal for Electrical And Electronic Engineering 10(2): 55-63.

Abu Alshair, M.J. 2007. Forecasting for Traffic accidents by using Box and Jenkins model, Al-Rafidain University College For Sciences (21): 1-14.

Al-Anbari, H.G. 2011. Head Injuries due to Motorcycle Accidents in Karabala-Iraq: Prospective Clinical Study, Karbala Journal of Medicine 4(3-4): 1170-1179.

Al-Ghabban, S.I.; AbdulSahib, M.; Waleed, M. 2013. Risk Factors and Pattern of Injuries in Motorcycle Accidents in Holy Karbala, Kerbala Jorunal of Medicine 6(1): 1552-1560.

Al-Hucheimy, A. 2014. Traffic Accidents in Thiqar Governorate during (2006-2012): A Study in Transport Geography, Master Thesis, University of Thiqar, Thiqar, Iraq.

Al-Joborae, S.F.; Al-Humairi, A.K. 2014. A Study of Road Traffic Accidents in Babylon Province, Medical Journal of Babylon 11(4): 912-922.

Al-Obaedi, J.T. 2015. Evaluation of Traffic Accidents Rates in Al-Diwaniya City, Journal of Babylon University 23(3): 571-578.

Al-Obaidi, S.M.; Yousif, H.H.; Al-Shalchy, A. 2007. An analytic study of 200 cases of head injuries admitted to teaching Hospital in Najaf, Journal of the Faculty of Medicine 49(1): 1-8.

Al-Sabbah, S.A. 2012. The most important factors affecting the accident according to the standard Bayesian future, Journal of Kerbala University (Scientific) 10(3): 127-134.

Al-Taei, A. 2010. Gap acceptance and traffic safety analysis on U-turn median openings of arterial roads, AL Rafdain Engineering Journal 18(6): 42-53. 
Ali, A.M. 2005. Road traffic accident fatalities in Tikrit general hospital, Medical Journal of Tikrit 2(112): 24-27.

Ali, S.F.; Abd, U.F. 2015. Measurement and classification of dangerous levels of traffic accidents in the provinces of Iraq, Journal of Kerbala University (Scientific) 13(02): 07-24.

Alwash, Q.M. 2012. Analysis of transport routes and the traffic situation in the city of Hilla, Journal of Babylon Center for Humanities Studies 2(1): 146-167.

Bordens, K.S.; Abbott, B.B. 2008. Research design and methods: A process approach. The McGraw-Hill Companies, Inc. USA. 628 p.

Central Statistical Organization (CSO) 2011. Statistics of private sector motorcars registered at the general directorate of traffic. Available from internet: <http:// www.cosit.gov.iq/en/trans-comm-statistics $>$.

Central Statistical Organization (CSO) 2013a. Report of traffic accidents statistics registered in 2010. Available from internet: <http://www.cosit.gov.iq/ar/2015-1123-08-05-11>.

Central Statistical Organization (CSO). 2013b. Summary of traffic accidents registered in 2009. Available from internet: <http://www.cosit.gov.iq/ ar/2015-11-23-08-05-11>.

Central Statistical Organization (CSO). 2013c. Traffic accidents statistics registered in 2012. Available from internet: <http://www.cosit.gov.iq/ar/2015-11-2308-05-11>.

Central Statistical Organization (CSO). 2013 d. Transportation and Communication Statistics Part 06. Available from internet: <http://cosit.gov.iq/ar/201312-18-07-31-11>.

Central Statistical Organization (CSO). 2014. Traffic accidents statistics registered in 2013. Available from internet: <http://cosit.gov.iq/ar/2015-11-23-08-05$11>$.
Central Statistical Organization (CSO). 2015a. Statistics of private sector motorcars registered at the general directorate of traffic. Available from internet: <http:// www.cosit.gov.iq>.

Central Statistical Organization (CSO). 2015b. Traffic accidents statistics registered in 2014. Available from internet: <http://www.cosit.gov.iq/ar/2015-11-2308-05-11>.

Central Statistical Organization (CSO). 2015c. Traffic accidents statistics registered in 2015. Available from internet: <http://www.cosit.gov.iq/ar/2015-11-2308-05-11>.

Central Statistical Organization (CSO). 2016a. Population of Iraq for the years 1978 - 2012. Available from internet: <http://www.cosit.gov.iq/en/industrialstatistics/smallfacilities?id=559>.

Central Statistical Organization (CSO). 2016b. Statistical summary. Available from internet: <http:// www.cosit.gov.iq/en/transportation?id=891>.

Central Statistical Organization (CSO). 2016c. Statistics of Private Motorcars up to 31/12/2015. Available from internet: <http://www.cosit.gov.iq/ar/2015-11-23-08-05-11>.

Coalition Provisional Authority (CPA). 2004. Iraqi Traffic Code (Traffic Law), Order No. 86. Available from internet: <http://www.iraqcoalition.org/regulations/>.

Dhahad, S.N. 2015. Traffic Accidents in Thi Kar Government Causes and Solutions, Basic Education College Magazine For Educational and Humanities Sciences (20): 639-655.

Ewadh, H.A 2006. Development of a rural road safety audit expert system (RRSAES), AL-Taqani Journal 19(2): 19-29.

Ewadh, H.A.; Neham, S.S. 2008. Traffic conflict technique: A tool for traffic safety study at three-leg signalized intersections, Journal of Kerbala University 6(1): $130-140$. 
Hadi, S.S. 2011. Parameters influence pedestrian traffic safety at urban unsignalized intersections, Engineering \& Technology Journal 29(14): 2973-2985.

Ismail, A.A. 2012. Comprehension of Posted Highway Traffic Signs in Iraq, Tikrit Journal of Engineering Sciences 19(01): 62-70.

Ismail, S.A.; Hasan, M.T. 2012. Epidemiology of Road Traffic Accidents in Emergency Hospital in Erbil City, Medical Journal of Tikrit 18(182): 296-305.

Jrew, B.; Abojaradeh, M.; Msallam, M.; AL-Kakaie, S.K. 2015. Management of Traffic Accidents for Principle Urban Streets in Arbil City in Iraq. In Proceedings of the Seventh Traffic Safety Conference, Amman, Jordan.

Marczyk, G.; DeMatteo, D.; Festinger, D. 2005. Essentials of research design and methodology. John Wiley and Sons Inc. New Jersey.USA. 301p.

Ministry of Planning. 2010. National Development Plan 2010-2014. Available from internet: <http://iq.one. un.org/documents/83/NDP\%20English.pdf $>$.

Ministry of Higher Education and Scientific Research 2016. Iraqi Academic Scientific Journals. Available from internet: < http://www.iasj.net/iasj>.

Mohammed, H.A. 2012. Study of traffic safety evaluation and improvements at unsignalized intersections, AlQadisiya Journal for Engineering Sciences 5(2): 150-165.

Mohammed, H.D.; Ahmed, A.M.; Ahmed, H.A. 2015. Statistical Analysis of Traffic Accidents Locations Using Geographic Information System in Darbandikhan TownKurdistan Region of Iraq, International Journal of Scientific and Engineering Research 6(5): 1831-1843.

Mohammed, W.M. 2011. Traffic accidents in the province of Diyala to the years 2009 and 2010, Journal of Research Diyala humanity (50): 511-536.
Mohammedhasan, Z.A. 2009. A Study of Motorcycle Accidents in Karbala City, Journal of Kerbala University 7(3): 154-168.

Mohan, D.; Tiwari, G; Khayesi, M; Nafukho, F. 2006. Road traffic injury prevention training manual. World Health Organization. Geneva.

Mudfon, A.A.; Abd Onn, N.A. 2005. Impact of environmental factors on traffic accidents in Al-Najaf city during 1995-2000, Journal of Kerbala University 3(13): 200-207.

Muhammad, S.A. 2006. Traffic mortality in year 2002 in Salahaddin governorate, Medical Journal of Tikrit 1(121): 25-28.

Naham, S.S. 2009. Predicted effectiveness countermeasure, Iraqi journal of mechanical and material engineering, Special issue C: 363-372.

O'Flaherty, C. ed., 1997. Transport planning and traffic engineering. Elsevier.

Peden, M.; Scurfield, R.; Sleet, D.; Mohan, D.; Hyder, A.; Jarawan, E.; Mathers, C. ed., 2004. World report on road traffic injury prevention. World Health Organization. Geneva.

Razouki, S.S.; Yasso, F.S.; Yaso, S.S.; Yasso, P.S.; Dafdony, I.V. 2013. Medical-Engineering Pattern of Severe Iraqi Road Traffic Accidents, American Journal of Medical Sciences and Medicine 1(5): 86-91.

Roess, R.P.; Prassas, E.; McShane, W. R. 2011. Traffic engineering ( $3^{r d} e d$.). Pearson Education International. 740 p.

The World Bank. 2016. Gross National Income (GNI) per capita Atlas method. Available from internet: $<$ http://data.worldbank.org/indicator/NY.GNP. PCAP.CD $>$. 
Tulfah, H.R. 2008. Traffic Accidents in Al-Diwanya City and Relationship with Congestion, Journal of College of Education 3(20): 154-168.

World Health Organization (WHO). 2011. Decade for action for road safety 2011-2020: global lunch. Available from internet: <http://www.who.int/roadsafety/ publications/decade_launch/en/>.
World Health Organization (WHO). 2015. Global status report on road safety 2015. Available from internet: <http://www.who.int/violence_injury_prevention/ road_traffic/en/>.

Zalzala, S.H.; Mahmood, K.K. 2013. Statistical study of traffic accidents in Iraq (in Arabic), Journal of Adminstartion and Economics (96): 213-221.

\section{Appendix}

\section{Table 1}

Summary of Traffic Accidents-Related Statistics in Iraq (Developed by the Author Based on a Spectrum of Sources)

\begin{tabular}{|c|c|c|c|c|c|c|c|c|c|c|c|}
\hline & 2005 & 2006 & 2007 & 2008 & 2009 & 2010 & 2011 & 2012 & 2013 & 2014 & 2015 \\
\hline $\begin{array}{l}\text { Population } \\
\text { estimation }\left(10^{6}\right)\end{array}$ & $27.9^{\mathrm{b}}$ & $28.8^{\mathrm{b}}$ & $29.6^{\mathrm{b}}$ & $31.8^{\mathrm{b}}$ & $31.6^{\mathrm{b}}$ & $32.4^{\mathrm{b}}$ & $33.3^{c}$ & $34.2^{\mathrm{d}}$ & $35.1^{\mathrm{d}}$ & $36.0^{\mathrm{d}}$ & $36.5^{\mathrm{e}}$ \\
\hline GNI per capita $(\$)$ & --- & $2020^{\mathrm{f}}$ & $2510^{\mathrm{f}}$ & $3530^{\mathrm{f}}$ & $4020^{\mathrm{f}}$ & $4410^{\mathrm{f}}$ & $4790^{f}$ & $6100^{f}$ & $6800^{f}$ & $6410^{\mathrm{f}}$ & $5550^{f}$ \\
\hline $\begin{array}{l}\text { No. of vehicles (in } \\
\text { millions) }\end{array}$ & --- & --- & $1.13^{\mathrm{c}}$ & $1.16^{\mathrm{c}}$ & $1.29^{c}$ & $1.39^{c}$ & $3.5^{\mathrm{cg}}$ & $3.83^{\mathrm{d}}$ & $4.51^{\mathrm{d}}$ & $5.38^{\mathrm{d}}$ & $5.66^{\mathrm{n}}$ \\
\hline No. of crashes & --- & $3389^{\mathrm{hkg}}$ & $3135^{\mathrm{ikg}}$ & $5502^{\mathrm{ikg}}$ & $7452^{\mathrm{ikg}}$ & $8861^{\mathrm{ikg}}$ & $10082^{\mathrm{kgg}}$ & $10709^{\mathrm{kj}}$ & $9725^{\mathrm{kj}}$ & $8814^{\mathrm{lk}}$ & $8836^{\mathrm{kk}}$ \\
\hline No. of fatal crashes & --- & $936^{\mathrm{gk}}$ & $945^{\mathrm{ikg}}$ & $1628^{\mathrm{ikg}}$ & $1955^{\mathrm{hkg}}$ & $2194^{\mathrm{ikg}}$ & $2372^{\text {okg }}$ & $2900^{\circ}$ & $2601^{\mathrm{kj}}$ & $2531^{\mathrm{pk}}$ & $2514^{\mathrm{lk}}$ \\
\hline No. of casualties ${ }^{a}$ & --- & $4454^{\text {hgk }}$ & $4462^{\mathrm{hgk}}$ & $7362^{\text {hgk }}$ & $10106^{\mathrm{hgk}}$ & $11504^{\mathrm{kg}}$ & $12901^{\mathrm{jgk}}$ & $14141^{j \mathrm{k}}$ & $13645^{\mathrm{jk}}$ & $11979^{\mathrm{lk}}$ & $11943^{l k}$ \\
\hline Death rate m $^{\mathrm{m}}$ & $7.8^{\mathrm{qk}}$ & $9.8^{\mathrm{qk}}$ & $12.5^{\mathrm{qk}}$ & $15.8^{\mathrm{qk}}$ & $16.2^{\mathrm{q}}$ & $18.0^{\mathrm{q}}$ & $17.0^{\mathrm{q}}$ & $17.9^{\mathrm{q}}$ & $17.6^{\mathrm{q}}$ & --- & --- \\
\hline
\end{tabular}

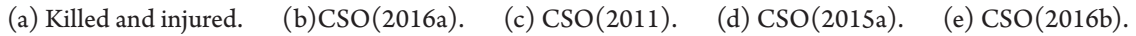

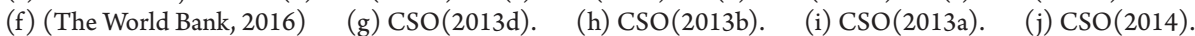

(k) Kurdistan region excluded. (1) $\mathrm{CSO}(2015 \mathrm{c})$. (m) Deaths per 100,000 people. (n) CSO(2016c)

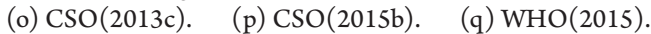

Table 2

Summary of the Traffic Accident Studies Retrieved and Reviewed by the Author

\begin{tabular}{|c|c|c|c|c|}
\hline Study & $\begin{array}{c}\text { Objective/ } \\
\text { Research question }\end{array}$ & $\begin{array}{c}\text { Data (source / } \\
\text { size / timescale / } \\
\text { coverage) }\end{array}$ & $\begin{array}{c}\text {-Research design } \\
\text { - Data analysis } \\
\text { method }\end{array}$ & Key findings / conclusions \\
\hline $\operatorname{Ali}(2005)$ & $\begin{array}{l}\text { Exploring road traffic } \\
\text { accident (RTAs) } \\
\text { mortality. }\end{array}$ & $\begin{array}{l}\text { Hospital records / } \\
\text { 4774 RTA victims } \\
\text { / } 1991 \text { - } 1996 \\
\text { / Salahaldin } \\
\text { province. }\end{array}$ & $\begin{array}{l}\text { - Descriptive study. } \\
\text { - Descriptive data } \\
\text { analysis. }\end{array}$ & $\begin{array}{l}\text { - RTA is the } 1^{\text {st }} \text { principal cause } \\
\text { of death for victims under } 40 \\
\text { years old. } \\
\text { - RTAs and mortality are } \\
\text { positively correlated with } \\
\text { number of vehicles. }\end{array}$ \\
\hline
\end{tabular}




\begin{tabular}{|c|c|c|c|c|}
\hline Study & $\begin{array}{c}\text { Objective/ } \\
\text { Research question }\end{array}$ & $\begin{array}{c}\text { Data (source / } \\
\text { size / timescale / } \\
\text { coverage) }\end{array}$ & $\begin{array}{l}\text {-Research design } \\
\text { - Data analysis } \\
\text { method }\end{array}$ & Key findings / conclusions \\
\hline $\begin{array}{l}\text { Mudfon and Abd } \\
\text { Onn (2005) }\end{array}$ & $\begin{array}{l}\text { Is there a correlation } \\
\text { between climate } \\
\text { factors and -traffic } \\
\text { accidents? }\end{array}$ & $\begin{array}{l}\text { Province Traffic } \\
\text { Directorate / RTA } \\
\text { Statistics / 1995 } \\
\text { - 2000 / Al-Najaf } \\
\text { province. }\end{array}$ & $\begin{array}{l}\text { - Correlational } \\
\text { study. } \\
\text { - Descriptive and } \\
\text { inferential data } \\
\text { analyses. }\end{array}$ & $\begin{array}{l}\text { - Dust, fog, rain and high } \\
\text { temperature affects rates of } \\
\text { collisions. } \\
\text { - Accident rates are high in } \\
\text { Winter and then in Summer. }\end{array}$ \\
\hline Ewadh (2006) & $\begin{array}{l}\text { Developing a safety } \\
\text { audit system for rural } \\
\text { roads. }\end{array}$ & $\begin{array}{l}\text { By researcher / } \\
\text { Site features and } \\
\text { traffic surveys / } \\
\text { Rural roads in Iraq. }\end{array}$ & $\begin{array}{l}\text { - Building an expert } \\
\text { system. } \\
\text { - Delphi method. }\end{array}$ & $\begin{array}{l}\text { - The developed safety audit } \\
\text { system is valid, effective and } \\
\text { flexible as crash preventive } \\
\text { system. }\end{array}$ \\
\hline $\begin{array}{l}\text { Muhammad } \\
(2006)\end{array}$ & $\begin{array}{l}\text { Exploring road traffic } \\
\text { injury mortality. }\end{array}$ & $\begin{array}{l}\text { Hospital records } \\
\text { / 173 RTA deaths } \\
\text { / during } 2002 \\
\text { / Salahaldin } \\
\text { province. }\end{array}$ & $\begin{array}{l}\text { - Descriptive study. } \\
\text { - Descriptive data } \\
\text { analysis. }\end{array}$ & $\begin{array}{l}\text { - Traffic mortality is the first } \\
\text { cause of death ( } 48 \%) \text {. } \\
\text { - About } 50 \% \text { of victims are } \\
\text { pedestrians. } \\
\text { - About } 66 \% \text { of pedestrians } \\
\text { involved with RTA are less } \\
\text { than } 20 \text { years old. }\end{array}$ \\
\hline $\begin{array}{l}\text { Abu Alshair } \\
(2007)\end{array}$ & $\begin{array}{l}\text { Developing road } \\
\text { traffic collision } \\
\text { forecasting model. }\end{array}$ & $\begin{array}{l}\mathrm{CSO}^{\mathrm{a}} \text { / RTA } \\
\text { statistics / 1979- } \\
1986 \text { / All over } \\
\text { Iraq. }\end{array}$ & $\begin{array}{l}\text { - Correlational } \\
\text { Study. } \\
\text { - Predictive data } \\
\text { analysis. }\end{array}$ & $\begin{array}{l}\text { - The developed model is } \\
\text { valid and can be applied for } \\
\text { forecasting future traffic } \\
\text { collisions. }\end{array}$ \\
\hline $\begin{array}{l}\text { Al-Obaidi et al. } \\
(2007)\end{array}$ & $\begin{array}{l}\text { To explore the } \\
\text { epidemiology of head } \\
\text { injuries. }\end{array}$ & $\begin{array}{l}\text { Hospital records } \\
\text { / } 200 \text { head injury } \\
\text { cases / 1996- } \\
1998 \text { / Al-Najaf } \\
\text { province. }\end{array}$ & $\begin{array}{l}\text { - Descriptive study. } \\
\text { - Descriptive data } \\
\text { analysis. }\end{array}$ & $\begin{array}{l}\text { - RTA is the cause of } 51 \% \text { of } \\
\text { head injuries; } 80 \% \text { of severe } \\
\text { injuries and } 70 \% \text { of deaths - } \\
\text { mainly are pedestrians. } \\
\text { - About } 50 \% \text { of pedestrians } \\
\text { involved with RTA are less } \\
\text { than } 15 \text { years old. }\end{array}$ \\
\hline Tulfah (2008) & $\begin{array}{l}\text { - To model the } \\
\text { relationship between } \\
\text { congestion and } \\
\text { spatial distribution of } \\
\text { road accidents. }\end{array}$ & $\begin{array}{l}\text { - Province Traffic } \\
\text { Directorate / RTA } \\
\text { Statistics / 1994 / } \\
\text { Al-Diwania City. } \\
\text { - Traffic field } \\
\text { surveys / 2008 / } \\
\text { Al-Diwania City. }\end{array}$ & $\begin{array}{l}\text { - Correlational } \\
\text { study. } \\
\text { - Inferential and } \\
\text { descriptive data } \\
\text { analyses. }\end{array}$ & $\begin{array}{l}\text { - There is a significant } \\
\text { positive correlation between } \\
\text { vehicle-vehicle collision } \\
\text { and determinants of traffic } \\
\text { congestion. } \\
\text { - The above is also true for run } \\
\text { over collisions. }\end{array}$ \\
\hline $\begin{array}{l}\text { Ewadh and } \\
\text { Neham (2008) } \\
\text { and } \\
\text { Naham (2009) }\end{array}$ & $\begin{array}{l}\text { To appraise safety } \\
\text { countermeasures } \\
\text { of intersections } \\
\text { using traffic conflict } \\
\text { technique. }\end{array}$ & $\begin{array}{l}\text { By researcher } \\
\text { / 4- and 3-leg } \\
\text { signalized } \\
\text { junctions survey / } \\
\text { in } 2003 \text { / Baghdad } \\
\text { City. }\end{array}$ & $\begin{array}{l}\text { - Correlational } \\
\text { study. } \\
\text { - Inferential data } \\
\text { analysis. }\end{array}$ & $\begin{array}{l}\text { - Strong relationships were } \\
\text { found linking hourly traffic } \\
\text { volume with the number of } \\
\text { traffic conflicts. } \\
\text { - Intersection geometry has an } \\
\text { impact on conflict rates. }\end{array}$ \\
\hline
\end{tabular}




\begin{tabular}{|c|c|c|c|c|}
\hline Study & $\begin{array}{c}\text { Objective/ } \\
\text { Research question }\end{array}$ & $\begin{array}{c}\text { Data (source / } \\
\text { size / timescale / } \\
\text { coverage) }\end{array}$ & $\begin{array}{c}\text {-Research design } \\
\text { - Data analysis } \\
\text { method }\end{array}$ & Key findings / conclusions \\
\hline $\begin{array}{l}\text { Mohammedhasan } \\
\text { (2009) }\end{array}$ & $\begin{array}{l}\text { To explore the } \\
\text { epidemiology of } \\
\text { motorcycle traffic } \\
\text { accident. }\end{array}$ & $\begin{array}{l}\text { By researcher / } \\
\text { Questionnaire } \\
\text { survey / } 300 \\
\text { motorcyclist / in } \\
2008 \text { / Karbala } \\
\text { City. }\end{array}$ & $\begin{array}{l}\text { - Correlational } \\
\text { study. } \\
\text { - Inferential and } \\
\text { descriptive data } \\
\text { analyses. }\end{array}$ & $\begin{array}{l}\text { - About } 44 \% \text { of motorcyclists } \\
\text { involved with an accident. } \\
\text { - } 66 \% \text { of accidents have not } \\
\text { been reported. } \\
\text { - } 42 \% \text { of accidents are because } \\
\text { of motorcyclists. } \\
\text { - While only } 43 \% \text { of } \\
\text { motorcyclists are less than } \\
18 \text { years, this cohort is the } \\
\text { most involved in accidents, } \\
\text { especially severe ones. }\end{array}$ \\
\hline Al-Taeie (2010) & $\begin{array}{l}\text { - To study traffic } \\
\text { accident association } \\
\text { with gap acceptance } \\
\text { on eight U-turn } \\
\text { median openings } \\
\text { along urban arterials. }\end{array}$ & $\begin{array}{l}\text { - Province Traffic } \\
\text { Directorate / RTA } \\
\text { Statistics / 2005- } \\
2007 \text { / Duhok } \\
\text { City. } \\
\text { - By researcher } \\
\text { / Field traffic } \\
\text { conflicts surveys } \\
\text { / } 2007 \text { / Duhok } \\
\text { City. }\end{array}$ & $\begin{array}{l}\text { - Correlational } \\
\text { study. } \\
\text { - Inferential and } \\
\text { descriptive data } \\
\text { analyses. }\end{array}$ & $\begin{array}{l}\text { - Traffic conflict frequency can } \\
\text { be a reasonable alternative to } \\
\text { accidents to depict safety near } \\
\text { U-turn median openings. } \\
\text { - Collision frequency is well } \\
\text { correlated with the major } \\
\text { traffic flow. }\end{array}$ \\
\hline Al-Anbari (2011) & $\begin{array}{l}\text { To interrogate the } \\
\text { epidemiology of } \\
\text { motorcycle crashes } \\
\text { resulting in head } \\
\text { injuries. }\end{array}$ & $\begin{array}{l}\text { Hospital records / } \\
168 \text { motorcyclists } \\
\text { with traffic head } \\
\text { injuries / Jan. } \\
\text { - Aug. } 2008 \text { / } \\
\text { Kerbala province. }\end{array}$ & $\begin{array}{l}\text { - Descriptive study. } \\
\text { - Inferential and } \\
\text { descriptive data } \\
\text { analyses. }\end{array}$ & $\begin{array}{l}\text { - Motorcyclists comprise the } \\
\text { majority of fatal and non-fatal } \\
\text { head injuries. } \\
\text { - They are generally males with } \\
\text { less than } 20 \text { years old. } \\
\text { - } 40 \% \text { of head injuries by } \\
\text { motorcycles are severe. }\end{array}$ \\
\hline Hadi (2011) & $\begin{array}{l}\text { To explore factors } \\
\text { affecting pedestrian } \\
\text { safety at junctions } \\
\text { using traffic conflicts } \\
\text { technique TCT. }\end{array}$ & $\begin{array}{l}\text { By researcher / } \\
\text { Traffic surveys for } \\
4 \text {-unsignalized } \\
\text { urban } \\
\text { intersections / in } \\
2010 \text { / Baghdad } \\
\text { province. }\end{array}$ & $\begin{array}{l}\text { - Correlational } \\
\text { study. } \\
\text { - Inferential and } \\
\text { descriptive data } \\
\text { analysis. }\end{array}$ & $\begin{array}{l}\text { - There is a strong and } \\
\text { significant relationship } \\
\text { between hourly pedestrian } \\
\text { conflict and each of the } \\
\text { following: hourly pedestrian } \\
\text { volume (positive); hourly } \\
\text { traffic volume (positive); } \\
\text { pedestrian walking speed } \\
\text { (negatively); average spot } \\
\text { speed (positive); approach } \\
\text { width (positive); pedestrian } \\
\text { delay (positive). } \\
\text { - The TCT is a reasonable and } \\
\text { reliable indicator for accidents. }\end{array}$ \\
\hline $\begin{array}{l}\text { Mohammed } \\
\text { (2011) }\end{array}$ & $\begin{array}{l}\text { - What are the most } \\
\text { contributing factors } \\
\text { of motor vehicle } \\
\text { collisions. } \\
\text { - What are the spatial } \\
\text { distribution of these } \\
\text { collisions. }\end{array}$ & $\begin{array}{l}\text { - Province Traffic } \\
\text { Directorate / } 400 \\
\text { RTAs / 2009-2010 } \\
\text { / Diyala Province. }\end{array}$ & $\begin{array}{l}\text { - Correlational } \\
\text { study. } \\
\text { - Descriptive data } \\
\text { analysis. }\end{array}$ & $\begin{array}{l}\text { - Highest rates of collision } \\
\text { occurred on Thursdays during } \\
\text { June to July. } \\
\text { - Vehicle-vehicle collision is } \\
\text { the commonest collision. } \\
\text { - Improper parking, wrong } \\
\text { turning and high speed are } \\
\text { major causes of crashes. }\end{array}$ \\
\hline
\end{tabular}




\begin{tabular}{|c|c|c|c|c|}
\hline Study & $\begin{array}{c}\text { Objective/ } \\
\text { Research question }\end{array}$ & $\begin{array}{c}\text { Data (source / } \\
\text { size / timescale / } \\
\text { coverage) }\end{array}$ & $\begin{array}{c}\text {-Research design } \\
\text { - Data analysis } \\
\text { method }\end{array}$ & Key findings / conclusions \\
\hline Alwash(2012) & $\begin{array}{l}\text { - What are the key } \\
\text { characteristics of road } \\
\text { traffic accidents? }\end{array}$ & $\begin{array}{l}\text { - Province Traffic } \\
\text { Directorate / } 774 \\
\text { RTAs / in } 2010 \text { / } \\
\text { Babil Povince. }\end{array}$ & $\begin{array}{l}\text { - Correlational } \\
\text { study. } \\
\text { - Inferential and } \\
\text { descriptive data } \\
\text { analysis. }\end{array}$ & $\begin{array}{l}\text { - Rate of fatalities per vehicles } \\
\text { is not negatively associated } \\
\text { with individual car ownership } \\
\text { as Smeed's law imposes. This } \\
\text { is mostly because traffic } \\
\text { awareness is not high enough. } \\
\text { - July is the month with } \\
\text { highest accident frequency. } \\
\text { - About } 62 \% \text { of accidents are } \\
\text { run over. }\end{array}$ \\
\hline $\begin{array}{l}\text { Ismail and Hasan } \\
\text { (2012) }\end{array}$ & $\begin{array}{l}\text { - To explore the } \\
\text { characteristics of road } \\
\text { accidents and their } \\
\text { contributing factors. }\end{array}$ & $\begin{array}{l}\text { Hospital records / } \\
180 \text { RTA victims / } \\
\text { Dec. } 2008 \text { / Arbil } \\
\text { Povince. }\end{array}$ & $\begin{array}{l}\text { - Correlational } \\
\text { study. } \\
\text { - Inferential and } \\
\text { descriptive data } \\
\text { analysis. }\end{array}$ & $\begin{array}{l}\text { - Majority of victims are males } \\
\text { with (21-30) years old and } \\
\text { pre-university education level. } \\
\text { - About } 75 \% \text { of victims are not } \\
\text { using safety seat belts. } \\
\text { - Majority of collisions } \\
\text { happened during day time and } \\
\text { by four-wheel cars. } \\
\text { - Over } 50 \% \text { of the casualties } \\
\text { are with head injury. }\end{array}$ \\
\hline Ismail (2012) & $\begin{array}{l}\text { To explore the link } \\
\text { between drivers's } \\
\text { involvement in } \\
\text { accidents and their } \\
\text { comprehension level } \\
\text { to roadside traffic } \\
\text { signs. }\end{array}$ & $\begin{array}{l}\text { By researcher / } \\
\text { Questionnaire } \\
\text { survey / Delivered } \\
\text { to } 1750 \text { drivers } \\
\text { / during } 2012 \text { / } \\
\text { Over Iraq. }\end{array}$ & $\begin{array}{l}\text { - Descriptive study. } \\
\text { - Descriptive data } \\
\text { analysis. }\end{array}$ & $\begin{array}{l}\text { Drivers' understanding of } \\
\text { the message a sign convey is } \\
\text { negatively associated with } \\
\text { the number of crashes he/she } \\
\text { involved in. } \\
\text { Generally drivers have low } \\
\text { comprehension level of signs; } \\
\text { especially those with low } \\
\text { education. }\end{array}$ \\
\hline $\begin{array}{l}\text { Mohammed } \\
\text { (2012) }\end{array}$ & $\begin{array}{l}\text { Examining } \\
\text { diagnostic approach } \\
\text { for evaluating } \\
\text { intersections safety as } \\
\text { an alternative to the } \\
\text { classic crash-based } \\
\text { approach. }\end{array}$ & $\begin{array}{l}\text { By researcher } \\
\text { / - Observational } \\
\text { survey for three } \\
\text { unsignalized } \\
\text { intersections / } \\
\text { during } 2011 \text { / Al- } \\
\text { Anbar Province. } \\
\end{array}$ & $\begin{array}{l}\text { - Descriptive study. } \\
\text { - Exploratory data } \\
\text { analysis. }\end{array}$ & $\begin{array}{l}\text { The diagnosis-based safety } \\
\text { evaluation approach works } \\
\text { well and with expected } \\
\text { saving in time and efforts in } \\
\text { comparison with accident- } \\
\text { based approach. }\end{array}$ \\
\hline $\begin{array}{l}\text { Al-Sabbah } \\
(2012)\end{array}$ & $\begin{array}{l}\text { Examining for the } \\
\text { factors affecting } \\
\text { the expected final } \\
\text { health condition of } \\
\text { the traffic accident } \\
\text { injured admitted to a } \\
\text { hospital. }\end{array}$ & $\begin{array}{l}\text { By researcher / } \\
\text { Questionnaire } \\
\text { survey / 135 RTA } \\
\text { patients / during } \\
2012 \text { / Karbala } \\
\text { Province. }\end{array}$ & $\begin{array}{l}\text { - Correlational } \\
\text { study. } \\
\text { - Inferential and } \\
\text { descriptive data } \\
\text { analysis. }\end{array}$ & $\begin{array}{l}\text { Type and severity of trauma } \\
\text { are the most influential factors } \\
\text { in expecting the final health } \\
\text { status of patients (to be } \\
\text { discharged, to be shifted to a } \\
\text { ward, or to be transferred to } \\
\text { the Intensive Care Unit). }\end{array}$ \\
\hline
\end{tabular}




\begin{tabular}{|c|c|c|c|c|}
\hline Study & $\begin{array}{c}\text { Objective/ } \\
\text { Research question }\end{array}$ & $\begin{array}{c}\text { Data (source / } \\
\text { size / timescale / } \\
\text { coverage) }\end{array}$ & $\begin{array}{c}\text {-Research design } \\
\text { - Data analysis } \\
\text { method }\end{array}$ & Key findings / conclusions \\
\hline $\begin{array}{l}\text { Al-Ghabban et al. } \\
(2013)\end{array}$ & $\begin{array}{l}\text { To explore the key } \\
\text { characteristics of } \\
\text { road motorcycles } \\
\text { collisions. }\end{array}$ & $\begin{array}{l}\text { By researcher / } \\
\text { Questionnaire } \\
\text { survey / } 456 \\
\text { RTA victims } \\
\text { (motorcycle riders } \\
\text { and passengers) / } \\
\text { Nov. } 2010 \text { - Feb. } \\
2011 \text { / Karbala } \\
\text { Province. }\end{array}$ & $\begin{array}{l}\text { - Correlational } \\
\text { study. } \\
\text { - Inferential and } \\
\text { descriptive data } \\
\text { analysis. }\end{array}$ & $\begin{array}{l}\text { - Nearly } 40 \% \text { of injured } \\
\text { motorcyclists (riders and } \\
\text { passengers) are less than } 20 \\
\text { years old. } \\
\text { - Almost two-thirds of } \\
\text { motorcyclists are only with } \\
\text { primary school education and } \\
\text { about third of them have a } \\
\text { collision history. } \\
\text { - Lower limb is the frequent } \\
\text { location of injuries and head } \\
\text { injuries are the main reason of } \\
\text { mortality. }\end{array}$ \\
\hline $\begin{array}{l}\text { Zalzala and } \\
\text { Mahmood } \\
(2013)\end{array}$ & $\begin{array}{l}\text { To explore possible } \\
\text { associations between } \\
\text { several contributing } \\
\text { factors and type of } \\
\text { highway accident. }\end{array}$ & $\begin{array}{l}\text { CSO / RTA } \\
\text { statistics / } 2006 \text { / } \\
\text { All over Iraq. }\end{array}$ & $\begin{array}{l}\text { - Correlational } \\
\text { study. } \\
\text { - Inferential and } \\
\text { descriptive data } \\
\text { analysis. }\end{array}$ & $\begin{array}{l}\text { - Majority of RTAs are } \\
\text { attributed to motorists. } \\
\text { - Fatality rates comprise: } \\
28 \% \text { of total crashes; } 18 \% \\
\text { collisions; } 46 \% \text { turn over; and } \\
33 \% \text { run over. } \\
\text { - Majority of road crashes } \\
\text { happened on main urban } \\
\text { roads; at daytimes; by a cohort } \\
\text { of motorists with ( } 24-35) \\
\text { years old; and by saloon } \\
\text { vehicles. }\end{array}$ \\
\hline $\begin{array}{l}\text { Razouki et al. } \\
(2013)\end{array}$ & $\begin{array}{l}\text { - To investigate the } \\
\text { possible reason(s) of } \\
\text { severe/fatal highway } \\
\text { collisions. }\end{array}$ & $\begin{array}{l}\text { By researcher / } \\
\text { Questionnaire } \\
\text { survey / } 1500 \text { RTA } \\
\text { victims / 2000- } \\
2006 \text { / Baghdad } \\
\text { Province. }\end{array}$ & $\begin{array}{l}\text { - Correlational } \\
\text { study. } \\
\text { - Descriptive data } \\
\text { analysis. }\end{array}$ & $\begin{array}{l}\text { - Severe traffic collisions- } \\
\text { injuries can be attributed to } \\
\text { excessive speed. } \\
\text { - Trauma severity can be } \\
\text { considerably decreased by } \\
\text { the availability and reliability } \\
\text { of First Aids at collision } \\
\text { site. - Similarly, utilizing } \\
\text { technological measures such } \\
\text { as seat belts and safety airbags } \\
\text { also can greatly lessen the } \\
\text { severity of injuries related to } \\
\text { traffic collisions. }\end{array}$ \\
\hline
\end{tabular}




\begin{tabular}{|c|c|c|c|c|}
\hline Study & $\begin{array}{c}\text { Objective/ } \\
\text { Research question }\end{array}$ & $\begin{array}{c}\text { Data (source / } \\
\text { size / timescale / } \\
\text { coverage) }\end{array}$ & $\begin{array}{l}\text {-Research design } \\
\text { - Data analysis } \\
\text { method }\end{array}$ & Key findings / conclusions \\
\hline $\begin{array}{l}\text { Al-Joborae and } \\
\text { Al-Humairi } \\
(2014)\end{array}$ & $\begin{array}{l}\text { To perform cross- } \\
\text { tabulation between } \\
\text { highway collision } \\
\text { features and type } \\
\text { of trauma; and to } \\
\text { investigate variables } \\
\text { affecting type of } \\
\text { trauma. }\end{array}$ & $\begin{array}{l}\text { - Hospital records } \\
\text { / } 37 \text { RTA deaths / } \\
\text { 6- months during } \\
2013 \text { / Babil } \\
\text { province. } \\
\text { - By researcher } \\
\text { / Questionnaire } \\
\text { survey / } 207 \\
\text { RTA victims / } \\
\text { 6- months during } \\
\text { 2013 / Babil } \\
\text { province. }\end{array}$ & $\begin{array}{l}\text { - Correlational } \\
\text { study. } \\
\text { - Inferential and } \\
\text { descriptive data } \\
\text { analyses. }\end{array}$ & $\begin{array}{l}\text { - Excessive speed is the most } \\
\text { reported reason for highway } \\
\text { collision. } \\
\text { - } 75 \% \text { of crash victims live in } \\
\text { urban locations; } 50 \% \text { with no } \\
\text { driving license; and about } 60 \% \\
\text { with collision history. } \\
\text { - Majority of these crashes } \\
\text { happened on major streets } \\
\text { during the times with clear sky } \\
\text { and good weather. } \\
\text { - Weather status; cause } \\
\text { of crash, and vehicle type } \\
\text { significantly affect trauma } \\
\text { type. }\end{array}$ \\
\hline Abid et al.(2014) & $\begin{array}{l}\text { To develop an } \\
\text { algorithm to support } \\
\text { and monitor motor } \\
\text { car remotely. }\end{array}$ & $\begin{array}{l}\text { - GPS technology } \\
\text { is employed to } \\
\text { decide vehicle } \\
\text { location and } \\
\text { speed. GSM } \\
\text { technology } \\
\text { is utilized for } \\
\text { communication } \\
\text { between } \\
\text { monitoring center } \\
\text { and the driver. }\end{array}$ & $\begin{array}{l}\text { - The system } \\
\text { was built by } \\
\text { graphical program. } \\
\text { Language and } \\
\text { simulated using } \\
\text { Proteus } 8 \text { tool for } \\
\text { Electronic Design } \\
\text { Automation. }\end{array}$ & $\begin{array}{l}\text { - The system can warn } \\
\text { motorists and monitoring } \\
\text { center when local speed limit } \\
\text { is exceeded. } \\
\text { - The system enables motorists } \\
\text { to report congestion location } \\
\text { which are accident-prone } \\
\text { spots. } \\
\text { - The system is capable of } \\
\text { inspecting airbag sensor and } \\
\text { informing the monitoring } \\
\text { center if the vehicle is being } \\
\text { involved in a crash. }\end{array}$ \\
\hline $\begin{array}{l}\text { Al-Hucheimy } \\
(2014)\end{array}$ & $\begin{array}{l}\text { To cross-tabulate } \\
\text { RTAs by trauma type; } \\
\text { and to investigate } \\
\text { variables affecting } \\
\text { type of trauma. }\end{array}$ & $\begin{array}{l}\text { Province Traffic } \\
\text { Directorate / } 3848 \\
\text { RTAs / 2006- } \\
\text { 2012 / Thi Qar } \\
\text { province. }\end{array}$ & $\begin{array}{l}\text { - Descriptive study. } \\
\text { - Exploratory and } \\
\text { descriptive data } \\
\text { analysis. }\end{array}$ & $\begin{array}{l}\text { - Human factors account for } \\
86 \% \text { of total collisions. } \\
\text { - Occurrence and rate of } \\
\text { collisions are much higher } \\
\text { in urban locations than in } \\
\text { suburbs and rural areas. } \\
\text { - There is a steep rise in } \\
\text { number of collisions during } \\
2006-2012 \text { period. }\end{array}$ \\
\hline Dhahad(2015) & $\begin{array}{l}\text { To explore patterns } \\
\text { and possible } \\
\text { contributing factors } \\
\text { of road accidents in } \\
\text { Thi Kar province. }\end{array}$ & $\begin{array}{l}\text { - Province Traffic } \\
\text { Directorate / } 3465 \\
\text { RTAs / 2004- } \\
2011 \text { / Thi Kar } \\
\text { Province. } \\
\text { - By researcher } \\
\text { / Questionnaire } \\
\text { survey / } 78 \\
\text { motorists / during } \\
\text { 2014 / Thi Kar } \\
\text { Province. }\end{array}$ & $\begin{array}{l}\text { - Correlational } \\
\text { study. } \\
\text { - Descriptive data } \\
\text { analysis. }\end{array}$ & $\begin{array}{l}\text { - During 2004-2011, there is } \\
\text { a clear increase in the vehicle- } \\
\text { to-vehicle accidents and their } \\
\text { resulted victims. } \\
\text { - Motorists report that, bad } \\
\text { road condition, absence } \\
\text { of regular maintenance for } \\
\text { vehicles and speeding are main } \\
\text { causes of accidents. }\end{array}$ \\
\hline
\end{tabular}




\begin{tabular}{|c|c|c|c|c|}
\hline Study & $\begin{array}{c}\text { Objective/ } \\
\text { Research question }\end{array}$ & $\begin{array}{c}\text { Data (source / } \\
\text { size / timescale / } \\
\text { coverage) }\end{array}$ & $\begin{array}{c}\text {-Research design } \\
\text { - Data analysis } \\
\text { method }\end{array}$ & Key findings / conclusions \\
\hline $\begin{array}{l}\text { Ali and Abd } \\
(2015)\end{array}$ & $\begin{array}{l}\text { To compute, classify } \\
\text { and examine the } \\
\text { hazard levels of road } \\
\text { crashes over Iraqi } \\
\text { provinces. }\end{array}$ & $\begin{array}{l}\text { General Traffic } \\
\text { Directorate / RTA } \\
\text { Statistics / in } 2012 \\
\text { / All over Iraq. }\end{array}$ & $\begin{array}{l}\text { - Descriptive study. } \\
\text { - Exploratory data } \\
\text { analyses }\end{array}$ & $\begin{array}{l}\text { - Iraqi provinces significantly } \\
\text { vary in traffic accident } \\
\text { characteristics. } \\
\text { - In terms of crash frequency, } \\
\text { Baghadad, Babil and Al-Najaf } \\
\text { are the highest } \\
\text { - In terms of crash fatality } \\
\text { Anbar, Salahaldin and Arbil } \\
\text { are the greatest. }\end{array}$ \\
\hline Jrew et al. (2015) & $\begin{array}{l}\text { - To identify crash- } \\
\text { prone locations and } \\
\text { - To build accident } \\
\text { occurrence and } \\
\text { severity statistical } \\
\text { models. } \\
\text { - To propose some } \\
\text { solutions. }\end{array}$ & $\begin{array}{l}\text { - Province Traffic } \\
\text { Directorate / RTA } \\
\text { statistics / 2010- } \\
2012 \text { / Arbil City. } \\
\text { - By researcher } \\
\text { / Questionnaire } \\
\text { survey / } 120 \\
\text { respondents / } \\
\text { during 2015 / } \\
\text { Arbil City. }\end{array}$ & $\begin{array}{l}\text { - Correlational } \\
\text { study. } \\
\text { - Inferential and } \\
\text { descriptive data } \\
\text { analyses. }\end{array}$ & $\begin{array}{l}\text { - Utilizing severity index, } \\
\text { several black spots have been } \\
\text { identified. } \\
\text { - Mortality is not significantly } \\
\text { linked to the roads' traffic and } \\
\text { geometric features. } \\
\text { - Underuse of crosswalks and } \\
\text { aggressive driving are observed } \\
\text { in the city. } \\
\text { - Traffic density, road status } \\
\text { and road users are leading } \\
\text { causes of collisions according } \\
\text { to respondents. }\end{array}$ \\
\hline $\begin{array}{l}\text { Al-Obaedi } \\
(2015)\end{array}$ & $\begin{array}{l}\text { To explore highway } \\
\text { crash rates and } \\
\text { possible contributing } \\
\text { factors. }\end{array}$ & $\begin{array}{l}\text { - Province Traffic } \\
\text { Directorate / } \\
\text { RTA statistics / } \\
2004 \text {-2013 / Al- } \\
\text { Diwaniya City. } \\
\text { - By researcher } \\
\text { / Questionnaire } \\
\text { survey / } 320 \\
\text { respondents } \\
\text { / 2014 / Al- } \\
\text { Diwaniya City. }\end{array}$ & $\begin{array}{l}\text { - Correlational } \\
\text { study. } \\
\text { - Descriptive data } \\
\text { analysis. }\end{array}$ & $\begin{array}{l}\text { - Collisions involving } \\
\text { pedestrians are greater than } \\
\text { those among vehicles. } \\
\text { - Half of the crashes are } \\
\text { attributed to the motorist and } \\
\text { about quarter attributed to the } \\
\text { vehicle. } \\
\text { - For each } 100000 \text { people the } \\
\text { city traffic mortality rate is } 33 \text {; } \\
\text { the worldwide average is as } \\
\text { low as } 18 \text {. } \\
\text { - The survey revealed that } \\
\text { unreported collisions are over } \\
20 \% \text {. Almost } 40 \% \text { of vehicle } \\
\text { has a collision history. }\end{array}$ \\
\hline $\begin{array}{l}\text { Mohammed et al. } \\
(2015)\end{array}$ & $\begin{array}{l}\text { To identify hazardous } \\
\text { locations spatially by } \\
\text { ArcGIS and classify } \\
\text { them based on } \\
\text { crash frequency and } \\
\text { severity. }\end{array}$ & $\begin{array}{l}\text { Province Traffic } \\
\text { Directorate / RTA } \\
\text { reports reports / } \\
2010-2012 \text { / Al- } \\
\text { Sulymaniya City. }\end{array}$ & $\begin{array}{l}\text { - Descriptive study. } \\
\text { - Exploratory and } \\
\text { descriptive data } \\
\text { analysis. }\end{array}$ & $\begin{array}{l}\text { - Spatial distribution and } \\
\text { priority of hazardous locations } \\
\text { can be well represented using } \\
\text { ArcGIS. } \\
\text { - Vast majority of collisions are } \\
\text { of vehicle-vehicle type. Over } \\
52 \% \text { of them are by passenger } \\
\text { cars. } \\
\text { - Majority of collisions } \\
\text { happened during daytime, } \\
\text { Thursday-Sunday and in June. }\end{array}$ \\
\hline \multicolumn{4}{|c|}{ a Central Statistical Organization - belongs to Iraqi Ministry of Planning. } & $\begin{array}{l}\text { b Obtained after calling the } \\
\text { researcher. }\end{array}$ \\
\hline
\end{tabular}




\section{Table 3}

Reviewed Studies Classified by Accident Measure (Indicators) and Principal Accident Contributing Factors

\begin{tabular}{|c|c|c|c|c|}
\hline & \multicolumn{4}{|c|}{ Traffic accident indicators } \\
\hline & Acc. Occurrence/rate & Acc. Involvement & Acc. Severity & Accident type \\
\hline $\begin{array}{l}\text { Road user } \\
\text { attributes }\end{array}$ & $\begin{array}{l}\text { Ali (2005); Al-Obaidi et al. } \\
\text { (2007); Al-Anbari (2011); } \\
\text { Hadi (2011); Ismail (2012); } \\
\text { Ismail and Hasan (2012); } \\
\text { Al-Joborae and Al-Humairi } \\
\text { (2014); Dhahad(2015); } \\
\text { Jrew et al. (2015); Al-Obaedi } \\
\text { (2015) }\end{array}$ & $\begin{array}{l}\text { Mohammedhasan } \\
\text { (2009); Al- } \\
\text { Anbari (2011); } \\
\text { Alwash(2012); } \\
\text { Al-Ghabban et al. } \\
\text { (2013); Al-Joborae } \\
\text { and Al-Humairi } \\
\text { (2014). }\end{array}$ & $\begin{array}{l}\text { Muhammad } \\
\text { (2006); } \\
\text { Mohammedhasan } \\
\text { (2009); Razouki et } \\
\text { al. (2013). }\end{array}$ & $\begin{array}{l}\text { Muhammad } \\
\text { (2006); } \\
\text { Mohammedhasan } \\
\text { (2009); Zalzala and } \\
\text { Mahmood (2013). }\end{array}$ \\
\hline $\begin{array}{l}\text { Road condition } \\
\text { (traffic, geometry, } \\
\text { and serviceability) }\end{array}$ & $\begin{array}{l}\text { Tulfah (2008); Ewadh and } \\
\text { Neham (2008) and Naham } \\
\text { (2009); Al-Taie (2010); } \\
\text { Razouki et al. (2013); } \\
\text { Dhahad(2015); Ali and Abd } \\
\text { (2015); Jrew et al. (2015); Al- } \\
\text { Obaedi (2015); Hadi (2011). }\end{array}$ & $\begin{array}{l}\text { Al-Joborae and Al- } \\
\text { Humairi (2014). }\end{array}$ & Jrew et al. (2015) & $\begin{array}{l}\text { Zalzala and } \\
\text { Mahmood (2013), } \\
\text { Razouki et al. } \\
\text { (2013). }\end{array}$ \\
\hline Weather condition & $\begin{array}{l}\text { Mudfon and Abd Onn } \\
\text { (2005); Mohammed (2011); } \\
\text { Alwash(2012). }\end{array}$ & $\begin{array}{l}\text { Al-Joborae and Al- } \\
\text { Humairi (2014). }\end{array}$ & & $\begin{array}{l}\text { Mudfon and Abd } \\
\text { Onn (2005). }\end{array}$ \\
\hline Vehicle condition & $\begin{array}{l}\text { Ali (2005); Tulfah (2008); } \\
\text { Ismail and Hasan (2012); } \\
\text { Abid et al.(2014); } \\
\text { Dhahad(2015); Mohammed } \\
\text { et al. (2015). }\end{array}$ & $\begin{array}{l}\text { Al-Joborae and Al- } \\
\text { Humairi (2014). }\end{array}$ & $\begin{array}{l}\text { Ali }(2005) ; \text { Al- } \\
\text { Anbari (2011); } \\
\text { Abid et al.(2014). }\end{array}$ & $\begin{array}{l}\text { Zalzala and } \\
\text { Mahmood (2013). }\end{array}$ \\
\hline $\begin{array}{l}\text { Crash condition } \\
\text { (type, location and } \\
\text { time) }\end{array}$ & $\begin{array}{l}\text { Al-Obaidi et al. (2007); } \\
\text { Tulfah (2008); } \\
\text { Mohammed(2011); } \\
\text { Alwash(2012); Ismail } \\
\text { and Hasan (2012); Al- } \\
\text { Hucheimy (2014); Zalzala } \\
\text { and Mahmood (2013); Ali } \\
\text { and Abd (2015); Al-Obaedi } \\
\text { (2015); Mohammed et al. } \\
\text { (2015); Dhahad(2015). }\end{array}$ & $\begin{array}{l}\text { Mohammed(2011); } \\
\text { Al-Joborae and } \\
\text { Al-Humairi } \\
\text { (2014); Al- } \\
\text { Hucheimy (2014); } \\
\text { Dhahad(2015). }\end{array}$ & $\begin{array}{l}\text { Zalzala and } \\
\text { Mahmood } \\
(2013) \text {; Ali and } \\
\text { Abd (2015); Jrew } \\
\text { et al. (2015); } \\
\text { Mohammed et al. } \\
\text { (2015). }\end{array}$ & $\begin{array}{l}\text { Tulfah (2008) } \\
\text {; } \\
\text { Mohammed(2011); } \\
\text { Alwash (2012); } \\
\text { Zalzala and } \\
\text { Mahmood } \\
\text { (2013); Al- } \\
\text { Hucheimy (2014); } \\
\text { Dhahad(2015). }\end{array}$ \\
\hline
\end{tabular}

